\title{
Article \\ A Multiple Criteria Decision Making Approach to Designing Teaching Plans in Higher Education Institutions
}

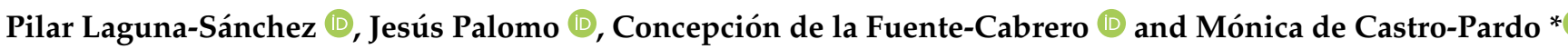 \\ Department of Business Economics, Faculty of Law and Social Sciences, University Rey Juan Carlos, \\ 28933 Madrid, Spain; pilar.laguna@urjc.es (P.L.-S.); jesus.palomo@urjc.es (J.P.); \\ concepcion.delafuente@urjc.es (C.d.l.F.-C.) \\ * Correspondence: monica.decastro@urjc.es
}

check for updates

Citation: Laguna-Sánchez, P.; Palomo, J.; de la Fuente-Cabrero, C.; de CastroPardo, M. A Multiple Criteria Decision Making Approach to Designing Teaching Plans in Higher Education Institutions. Mathematics 2021, 9, 9. https://dx.doi.org/10.3390/ math9010009

Received: 23 November 2020 Accepted: 20 December 2020 Published: 22 December 2020

Publisher's Note: MDPI stays neutral with regard to jurisdictional claims in published maps and institutional affiliations.

Copyright: () 2020 by the authors. Licensee MDPI, Basel, Switzerland. This article is an open access article distributed under the terms and conditions of the Creative Commons Attribution (CC BY) license (https: / / creativecommons.org/ licenses/by/4.0/).
Abstract: The involvement of competences in the teaching-learning planning process in Higher Education is essential for their success in the European Higher Education Area. This study presents a participatory multi-criteria model based on Voting Analytic Hierarchy Process (VAHP) analysis, focusing on the attainment of competences that permits consensus between lecturers and students in the design of teaching plans using two assessments: the assessment of competences by students and the lecturers' assessment of the contribution of teaching strategies to the attainment of each competence. To validate the methodology, a survey was carried out to determine the preferences of 211 students on the competences of a quantitative subject in several business degrees and a survey of 11 lecturers to assess the contribution of the teaching strategies in the acquisition of each competence. The results show that practical lessons and group work should receive more importance in the teaching plans of the subject Financial Management according to the defined competences, the students' preferences and the criterion of each lecturer for each teaching strategy. The results show the applicability of the participatory methodology proposed to formally agree on the design of teaching plans in higher education organizations between lecturers and students.

Keywords: MCDM; participative management; VAHP; competences; Borda count; Higher Education Institutions; teaching-learning process planning

\section{Introduction}

Higher education organizations are involved in a changing environment, and their position in global contexts increasingly depends on their ability to adapt to the environment, together with the continuous improvement of teaching and research activities [1]. In this context, external stakeholders require transparency and accountability and the main challenge for higher education institutions lies in rethinking their role in the higher education landscape to consider and improve their performance profiles, i.e., how good higher education institutions are at performing their activities [2].

The modern concept of the university as a "stakeholder university" vs. "republic of scholars" implies the need to adapt to new government policies that address how higher education institutions should be run and organized [3]. On the other hand, the orientation towards human capital formation, that is, professionals from an innovative perspective and oriented to the current labor market is a reality that cannot be overlooked [4]. This requires paying attention to three issues: planning, the teaching-learning process and learning outcomes.

Due to increased global competitiveness and increased expectation and challenges, higher education organizations need to carefully define their institutional profiles [2]. Using this approach, strategic plans and governance processes can support branding policies to define the institutional profile from a management approach [3]. Both topics could respond perfectly to two key questions regarding management: how and when. 
However, the essence of universities lies in the quality of these three issues: planning, the teaching-learning process and learning outcomes. Thus, to define the profile of the higher education organizations completely, it is necessary to add tools able to respond to a third question related to education planning: why. This question is directly related to the goals of the teaching-learning process. At present, in some European universities, for example in Spain, educational plans are defined principally by the lecturers, and students are present in the Curriculum Commissions in a very minor way. Student participation is defined by each university [5]. Therefore, occasionally the preferences of the main stakeholder involved in the teaching-learning process, the students, are not considered. However, to ensure the quality of the teaching-learning process it is necessary for the goals of the lecturers and students to be aligned [6-8]. In this work quality is understood to be "the result of the interaction between lecturers, students, and the learning environment in which program content, learning opportunities, and resources are tailored to their purposes" [9].

Concern about including the participation of students in higher education governance, has increased in the last decade [10]. Although some authors remark that there is a lack of a rigorous definition of what quality means in higher education and that quality does not normally consider the preferences of the students [11]. Furthermore, some studies show the utility of students' preferences to evaluate services in order to improve their quality and the overall perception of lecturers by the students. In fact, Ref. [7] highlight the importance of higher education institutions to "have a deep understanding of shared responsibility between participants and further emphasize the importance of consumer responsibility to play an active role in shaping the value of their experiences".

Moreover, there are some studies that have focused on connecting lecturers and students in order to discuss the most effective teaching and learning methods [11,12]. Specifically, Ref. [11] stress the relevance of flexibility in teaching plans and the participation of students to ensure the quality of these plans. The goal in the long term is to offer support to the higher education institutions in order to build participative teaching and learning plans without losing rigor, effectiveness and efficiency. This participative approach permits the closing of the gap between the goals and teaching methodology, and the expectations of the students [11].

In spite of this, and the fact that the legislation [5] provides for this participation, the reality is that usually students have a low level of involvement as co-decision makers for education planning. This can result in divergences between the teaching objectives and the expectations of the students, decreasing the motivation of the students and reducing the quality of the learning process $[13,14]$.

In the complex context of higher education, competence-based teaching has been implanted successfully in a large number of universities. In fact, "the majority of the institutions designed their education through a mix of traditional and competence-based teaching and assessment methods" [15]. A consolidated example of the strength of competencebased-learning is the European Higher Education Area (EHEA). The EHEA is a dynamic, complex, student-focused system that replaces the traditional learning system by focusing on linear learning using a multi-approach learning system based on an interdisciplinary context $[16,17]$. With this new approach, it is necessary to include the preferences of all the stakeholders to ensure the efficiency of the teaching policies [18]. In this context, the student assumes a very important role in the design and assessment of the teaching plans [19]. In this line, the references of quality of the European model in higher education recommend prioritizing the development of the methodologies for assessment that include the participation and autonomy of the students in the teaching process [20]. Therefore, it is necessary to highlight the concern of European universities about innovation. Specifically in [21], issues related to the future of the EHEA were discussed, and the relevance of "supporting higher education institutions in their efforts to start or maintain a structured dialogue on innovation and enhancement of learning and teaching, involving students, lecturers and also relevant external stakeholders" was stressed emphasizing the orientation 
towards learning outcomes and the consideration of skills to address the current and future challenges of society [21].

The students themselves could be the best referees to assess the achievement of the competences and it seems essential to include their perceptions relating to the goals for the teaching-learning process defined by teaching plans [22-25]. The loss of communication between students and other stakeholders linked to the education system, such as lecturers but also the institutions themselves, can create gaps that decrease the accuracy of defining competence goals. A good way to compare teaching units to the study programs of higher education institutions is to analyze the results in terms of the achievement of the competences. Therefore, it is necessary to define the results of learning correctly and establish criteria related to the content and global competences of each subject [26]. Moreover, it is important not to lose sight of the goal of preparing students for impact-focused careers [27]. However, this is only possible when an optimal combination of the competences for each subject and level occurs [28] together with a continuous assessment of teaching strategies to ensure the attainment of the academic goals by the students [29].

The main goal of this paper is to provide a Multiple Criteria Decision-Making (MCDM) methodology that permits the avoidance of divergences between the expectations of the students and both the competence/goal focus, related to some subjects, and the teaching strategies used by the lecturers to reach these goals.

\section{Literature Review}

The aggregation of individual preferences is a complex process, and problems frequently appear in relation to consistency with the consensus of group assessment and with social legitimacy problems related to ethical topics. From a rational approach, considering the different preferences and interests of the different individuals in society, the huge problem of social choice is based on how to relate social preferences and joint decisions to individual values and interests [30]. On one hand, this could be a problem associated with the manipulability of the social decision function. On the other hand, when decision-making problems need to consider several alternatives from different criteria, the complexity of the aggregation process increases, and it is essential to include the individual valuations with rigor [31]. In this context, a multi-criteria analysis can provide rigor to participative decision-making models when it is essential to ensure minimum objectivity, representativity and transparency in a global and democratic context [32,33].

In recent years, the growing relevance of participative processes related to teaching policies in higher education has driven the development of new methodologies pinpointed by the optimization of group consensus [18]. Specifically, in higher education, MCDM has been efficient in obtaining joint assessments in this context [22]. In fact, these techniques have worked well in the planning and assessment of complex projects and have been used to design public policies when it is necessary to obtain a global assessment from multiple individuals and a high number of stakeholders [34].

Some reviews present the frequent use of Analytic Hierarchy Process (AHP) in the area of education [35]. AHP considers individual preferences and assessments of value judgements about the relative importance of the analyzed criteria constructing pairwise matrices [35]. The combined use of the AHP with other MCDM techniques such as Goal Programming (GP), Fuzzy sets (FST) or the Analytic Network Process (ANP) is normal. GP is a linear programming technique that helps to solve complex problems through an optimization process that looks for compromise solutions that may not fully satisfy all the goals but do reach certain satisfaction levels set by the decision-maker [36]. Fuzzy logic was originally developed by [37] and permits representing vague knowledge to model decision-making problems [38]. The ANP [39] applies a similar logic to the AHP method but using network relations instead of pairwise relationships.

Ref. [40] carried out a more in-depth review in which they analyzed more than 42 papers on the application of multi-criteria methods to assess the efficiency of e-learning 
showing that the most used methods are AHP and AHP combined with other methods, usually fuzzy methods.

So far, AHP has not been applied to assess classroom higher education, but some studies have applied it to assess user satisfaction in online courses. Ref. [41] considers four main dimensions to assess the support system in an e-learning context: Learner Interface, Learning Community, System Content and Personalization. Ref. [42] assesses the applicability of an e-learning system in a computer course, combining AHP with another multi-criteria method: Goal Programming. Ref. [43,44] also proposes an evaluation model based on AHP and Fuzzy methods. On the other hand, Ref. [21] uses AHP combined with Analytic Network Process (ANP) in higher education to analyze the preferences of the stakeholders and they present a case study, with the prioritization of five projects, about the use of the resources in universities.

The use of voting methods in education has been studied from different points of view. Some studies propose digital methods as a way to obtain student votes in a classroom [45]. Ref. [46] analyzes the assessment by the lecturer and the students of different alternatives in the content of a subject. On the other hand, some research has shown the utility of combined analysis based on voting and multi-criteria methods [47-49].

\section{Methods}

\subsection{Description of the Method and Justification}

The proposed methodology focuses on the acquisition of competences and provides a consensus between lecturers and students in the design of the teaching plans as a result of a double assessment: the assessment of the teaching strategies and the assessment of the objectives in terms of the achievement of competences.

This methodology uses a mixed multi-criteria analysis: the voting analytic hierarchy process (VAHP). Multi-criteria analysis provides rigor to the participative decision-making processes [50,51]. On the other hand, voting methods allow aggregation in a simple way, regarding individual preferences in only one global assessment [52].

AHP deals with subjective preferences and allows the researcher to quantify trade-offs using a paired comparison between criteria [53], and to prioritize different alternatives. Therefore, AHP obtains the individual preferences and assessments through opinions about the relative importance of the paired criteria and alternatives. In the educational context, AHP has been used frequently [36], although it presents some limitations. Firstly, when it uses subjective valuations it is necessary to validate the consistency of the primary results. In addition, when the number of criteria is high, the survey becomes too complex and the process can become tedious and difficult as it results in a very high number of paired comparisons to evaluate.

The combination of the voting methods with hard multi-criteria techniques like the AHP method can make it easier to obtain consistent results when the participants are not experts, as in the case of students. Additionally, it allows the researcher to deal with a higher number of criteria without losing the operativity of the process [54].

The students are the main stakeholders involved in the teaching-learning process, although considering the preferences of the students is not common when designing teaching plans. Nevertheless, lecturers should use teaching strategies and other tools in the classroom with one objective: the acquisition of skills as defined in the teaching plan of any given subject. This objective is related to the global and transversal competences and the specific competences, but it is not usual to establish priorities between them. On the other hand, students have perceptions about the importance of these competences but as of yet a formal model that obtains their preferences does not exist. In addition, the teaching strategies used by lecturers might not meet the expectations of the students in this sense.

The proposed model is capable of identifying preferences about the relevance of particular competences, related to one of the student's subjects, using a voting method. It simultaneously permits the addition of criteria from the lecturers about the contribution of 
each resource in relation to each competence. This provides the lecturers with more flexibility to fit the resources to the expectations of the students in relation to the learning process of the subject, the acquisition of the key competences and should help improve motivation.

The methodology is based on two assessments: (1) the students assess the competences related to a subject and (2) the lecturers assess the contribution of the teaching strategies available to help students obtain these competences.

The model Voting Analytic Hierarchy Process (VAHP) proposes using a voting method based on the Borda count combined with AHP to aggregate the priorities of the students with the global and specific competences related to a subject or grade in a simple way. The Borda count aggregation method can be explained as follows: by giving each candidate or alternative, a number of points corresponding to the number of candidates ranked lower. The candidate that obtains the most points is the Borda winner [55].

The hierarchy of the model is defined on two levels. The first level shows the global objective: to identify the best teaching strategies needed to obtain the competences as defined in a subject teaching plan. The second level is formed by the dimensions or competences that need to be assessed. Therefore, to achieve the global objective, this model is defined in three steps:

I. Assessment 1: this is based on an assessment by the students about the relevance of the competences related to a subject. The model allows the analyst to obtain normalized weights that represent the most preferred competences by the students.

II. Assessment 2: this is based on an assessment by the lecturers of the contribution of each teaching resource to achieve one competence related to a subject. The model allows the analyst to obtain normalized weights that represent the most relevant teaching strategies for each competence.

III. Final result: this is the result after the aggregation of assessment 1 and assessment 2 and represents a final score for each resource related to their contribution towards the acquisition of the most preferred competences by the students.

Figure 1 shows a visual description of the process.

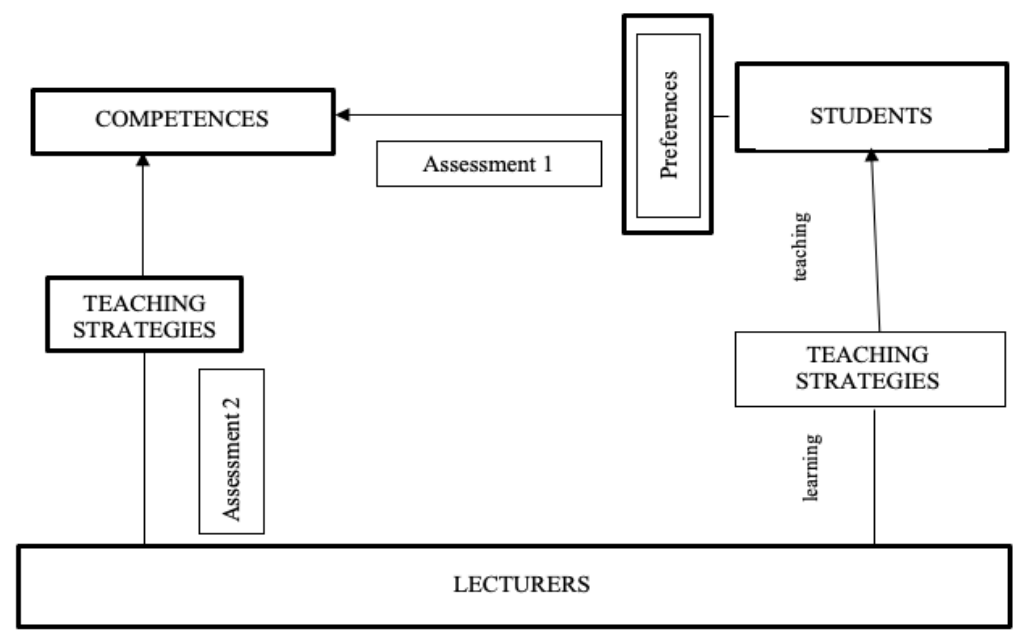

Figure 1. Description of the process.

\subsection{Assessment 1: Assessment of the Competences by the Students}

To obtain information about the preferences of the students in relation to one particular subject, we presented a survey to each student that aimed to determine their opinion about the relevance of each competence. The objectives of the study and the criteria were explained to the students. The survey provided the individual with the opportunity to vote and these results were dealt with using a Borda count. As a result of the participative process, a conjoint ranking for the individual preferences about the competences was obtained. 
Voting methods provide different options to choose the most preferred alternative from a group. However, it is not possible to get a measure of the robustness of each option, i.e., it is not possible to obtain the weight of preference for each of the ranked items.

This model provides a ranking of the competences based on the relevance of the related criteria. The ranking and weights are calculated as follows:

- Criteria Rank: the students assign marks to each competence using a number from 1 to $\mathrm{V}(\mathrm{V} \leq \mathrm{C})$, where $\mathrm{C}$ is the number of competences or criteria in order of relevance.

- Conjoint Result: the calculation of the weight is based on [36]. For the $C$ criteria and competences, $\mathrm{n}_{\mathrm{s}}$ students and $V_{s}$ votes, the largest score $\eta_{c c}$ (for the criteria $c$ when you get a score vsth in the preferences) is defined as a result of the maximum of the sum of the votes for the $c$ th criteria.

$$
\eta_{c c}=\max \sum_{v s=1}^{V s} u_{c v s} x_{c v s}
$$

where $x_{c v s}$ is the total number of the votes for the criteria $c$ with a vote $v_{S}$ of the $n_{S}$ students, $c=\{1,2, \ldots, C\}, v_{s}=\{1,2, \ldots, C\}$,

$$
\begin{gathered}
\text { s.t. } \eta_{c p}=\sum_{v s=1}^{V s} u_{c v s} x_{p v s} \leq 1, p=\{1,2, \ldots, C\} \\
u_{c v s}>0, u_{c v s}-u_{c v s}+1 \geq d\left(v_{s}, \delta\right)=\delta>0, \text { i.e., } u_{c 1}>u_{c 2}>\cdots>u_{c v}>\cdots \geq \delta \\
u_{c 1} \geq 2 u_{c 2} \geq \cdots>V_{s} u_{c v s} \text { and } u_{c v s} \geq \delta
\end{gathered}
$$

where

$$
\delta=\frac{2}{V_{s}\left(V_{s}+1\right) n_{s}}
$$

where constraint (3) refers to a weak order, constraint (4) refers to a strong order and constraint (2) is necessary to obtain normalized weights.

The Equation (1) is applied in the majority of the voting methods based on score rules. Specificaly, the desirability of the criteria $c$ defined in (1), where $x c_{v s}$ is the number of $v s t h$ places that the criteria c obtains from the students. This is applied when:

- $\quad$ Rule of priority: the weights $u_{c v s}$ obtain the value $u_{c 1}=1, u_{c v s}=0, \forall v_{s} \geq 2$, i.e., only the first option of each participant is considered $v_{s}=1$.

- Borda count: each participant ranks their preferences of the $C$ criteria and competences, assigning $n_{s}$ votes to the preferred candidate, $n_{s}-1$ to the second choice and, finally 1 to the least preferred candidate.

\subsection{Assessment 2: Assessment of the Contribution of Teaching Strategies for Each Competence by the Lecturers}

The assessments of the lecturers are obtained through a survey that includes some questions about the contribution of the teaching strategies in the acquisition of the competences.

The application of Equations (1)-(4) in $r$ teaching strategies and $t$ lecturers, provides a ranking of the most competent teaching strategies for any one competence. The ranking and the weights are calculated in the same way as assessment 1.

\subsection{Final Results: Provide a Rank That Highlights the Best Fitting Teaching Strategies Capable of Obtaining the Competences Most Preferred by the Students}

Finally, to aggregate the assessments of the lecturers and the preferences regarding the competences of the students, this model uses a linear aggregation method (Equation (5)).

$$
\eta_{r c}=\sum_{c}^{C} \eta_{c c, c} \eta_{r r, c}
$$

where $\eta_{r c}$ is the final score for each resource related to their contribution to the acquisition of the $C$ competences analyzed, $\eta_{c c}$ is the weight for the competence $c$ obtained in assessment 
2 and represents the largest score for each competence voted on by the students, and $\eta_{r r}$ is the weight for the resource $r$ obtained in assessment 2 and represents the largest score of the contribution of each resource about each competence voted on by the lecturers.

Linear aggregation methods are useful when all individual criteria have the same measurement unit and the analyst wants compensability between them [56,57]. Therefore, this method allows us to obtain a ranking of the most important teaching strategies related to a subject, based on the importance, in the opinion of the students, of each competence. This importance is quantified by the weights obtained in assessment 1 . Consequently, the conjoint result merges the know-how of the lecturers with the expectations of the students in relation to one particular subject and provides a guide to designing participative teaching plans and the improvement of existing plans.

\section{Case Study}

The model was validated on the basis of two different samples. Sample 1 was formed by 211 students from the University Rey Juan Carlos. The students were divided into four groups from different subjects: Business Administration and Management (BAM); Law and BAM; Tourism and BAM; and Advertising and Public Relations (APR) and BAM, in the third and fourth years (Table 1). The ages were between 20 and 38, they started university between 2002 and 2017, and the first year of the degree was between 2010 and 2017. $61.61 \%$ of the participants were women and $38.39 \%$ men. This survey was carried out through the platform Google Forms in classroom.

Table 1. Degree and course of the students.

\begin{tabular}{ccc}
\hline Degree & Participants & Stage \\
\hline BAM & 76 & Third Year \\
Law and BAM & 43 & Fourth Year \\
Tourism and BAM & 50 & Fourth Year \\
APR and BMA & 36 & Fourth Year \\
Others & 6 & - \\
\hline
\end{tabular}

Sample 2 was formed by 11 lecturers of the subject Financial Management at the same university. This second survey was carried out in a lecturers' meeting.

These two questionnaires can be found as Supplementary Material Q1 and Q2.

We partially followed the University Students' Expectations of Teaching (USET) survey [12] and the Socrates funded CEESOC project (Comparison of Expectations of European Students on ODL Courses) to develop two surveys that allowed us to obtain the preferences of students regarding the most important competences for them and information about the combination of teaching strategies that best fit these expectations. Survey 1 allowed us to obtain the relevance of 9 competences (Table 2) using a score from 1-10. The survey was presented to sample 1, formed by students of the subject Financial Management. Survey 2 allowed us to obtain opinions about the contribution of five teaching strategies for each of the nine competences analyzed. Survey 2 was presented to sample 2, consisting of lecturers.

The criteria in the survey were: 7 generic competences and 2 subject specific competences (Table 2) related for the subject Financial Management. A description of each is shown in the Grade Memory in Business Administration and Management. 
Table 2. Generic and subject specific competences (based on [26]).

\begin{tabular}{|c|c|c|}
\hline Competences & Type & Description \\
\hline GC1-Capacity for analysis and synthesis & Generic & $\begin{array}{l}\text { Identify and describe the elements of a reality and organize the most } \\
\text { significant information based on pre-defined criteria. }\end{array}$ \\
\hline GC2-Information management skills & Generic & $\begin{array}{l}\text { Ability to retrieve and analyze information from different sources } \\
\text { and use it efficiently to solve a problem, make a decision and be able } \\
\text { to communicate it }\end{array}$ \\
\hline GC3-Decision making & Generic & $\begin{array}{l}\text { Analyze a problem and choose between different alternatives to } \\
\text { optimize the expected result as a result of the action }\end{array}$ \\
\hline GC4-Capacity to learn & Generic & Assimilation of new information and being able to apply it efficiently \\
\hline GC5-Ability to work autonomously & Generic & Work autonomously without support \\
\hline $\begin{array}{l}\text { GC6-Capacity to apply } \\
\text { knowledge practically }\end{array}$ & Generic & Contextualize and adapt theoretical contents in real situations \\
\hline GC7-Problem solving & Generic & $\begin{array}{l}\text { Identify difficulties in the development of a project and choose an } \\
\text { alternative way to solve it }\end{array}$ \\
\hline $\begin{array}{l}\text { SC1-Comprehension of financial } \\
\text { operations in the business environment }\end{array}$ & Specific & $\begin{array}{l}\text { Select the best information to understand the financial operations in a } \\
\text { business framework }\end{array}$ \\
\hline $\begin{array}{l}\text { SC2-Problem solving regarding } \\
\text { financial valuation }\end{array}$ & Specific & $\begin{array}{l}\text { Learning, understanding and applying knowledge and contributing } \\
\text { towards intellectual autonomy in a framework of financial valuation. }\end{array}$ \\
\hline
\end{tabular}

The criteria valuated by the lecturers were: theoretical lessons, practical lessons, group activities, group presentations and related activities (Table 3).

Table 3. Teaching strategies available for lecturers.

\begin{tabular}{cc}
\hline Teaching Strategies & Description \\
\hline R1-Theoretical lessons & Traditional classes to explain theoretical contents \\
R2-Practical lessons & Traditional classes to solve problems, practical exercises and case studies. \\
R3-Group activities & Group homework or classroom based group work \\
R4-Group presentations & Presentations of the projects to a classroom audience \\
R5-Activities related to the subject & Conferences, seminars. \\
\hline
\end{tabular}

The model was applied in the case study as follows; firstly, Equation (1) was applied considering constraints (2), (3) and (4), where $x_{c v s}$ is the total number of votes for competence $c$ with a vote $v_{s}$ from the 211 students, therefore, $c=\{1,2, \ldots, 9\}, v_{s}=\{1,2, \ldots, 9\}$. Secondly, we reapplied the model with $x_{r v t}$ number of votes for resource $\mathrm{r}$ with a vote $v_{t}$ from the 11 lecturers, therefore $r=\{1,2, \ldots, 5\}, v_{t}=\{1,2, \ldots, 5\}$. We obtained the final score using Equation (5) where $\eta_{c c}$ is the weight for each competence obtained in assessment 2 and represents the largest score of the 9 competences valuated by the 211 students, and $\eta_{r r}$ is the weight for each resource obtained in assessment 2 and represents the largest score of the 5 strategies valuated by the 11 lecturers.

\section{Results and Discussion}

The results of the surveys of the analyzed subject are described as follows. Table 4 presents the results of the voting process of the 211 students in relation to the relevance of each competence analyzed.

Table 4. Result of the voting process for the students in relation to the importance of the competences.

\begin{tabular}{ccccccccccc}
\hline Competences & $\mathbf{1}^{\mathbf{0}}$ & $\mathbf{2}^{\mathbf{o}}$ & $\mathbf{3}^{\mathbf{o}}$ & $\mathbf{4}^{\mathbf{o}}$ & $\mathbf{5}^{\mathbf{o}}$ & $\mathbf{6}^{\mathbf{o}}$ & $\mathbf{7}^{\mathbf{o}}$ & $\mathbf{8}^{\mathbf{0}}$ & $\mathbf{9}^{\mathbf{o}}$ & Total \\
\hline SC1 & 33 & 30 & 36 & 13 & 16 & 17 & 15 & 31 & 20 & 211 \\
SC2 & 28 & 35 & 22 & 26 & 20 & 19 & 25 & 20 & 16 & 211 \\
\hline
\end{tabular}


Table 4. Cont.

\begin{tabular}{ccccccccccc}
\hline Competences & $\mathbf{1}^{\mathbf{o}}$ & $\mathbf{2}^{\mathbf{o}}$ & $\mathbf{3}^{\mathbf{o}}$ & $\mathbf{4}^{\mathbf{o}}$ & $\mathbf{5}^{\mathbf{o}}$ & $\mathbf{6}^{\mathbf{o}}$ & $\mathbf{7}^{\mathbf{o}}$ & $\mathbf{8}^{\mathbf{o}}$ & $\mathbf{9}^{\mathbf{o}}$ & Total \\
\hline GC1 & 1 & 10 & 20 & 22 & 18 & 32 & 32 & 30 & 46 & 211 \\
GC2 & 4 & 6 & 10 & 24 & 37 & 34 & 34 & 36 & 26 & 211 \\
GC3 & 23 & 17 & 33 & 30 & 46 & 26 & 19 & 9 & 8 & 211 \\
GC4 & 25 & 20 & 18 & 25 & 25 & 33 & 26 & 24 & 15 & 211 \\
GC5 & 21 & 18 & 26 & 16 & 18 & 19 & 30 & 22 & 41 & 211 \\
GC6 & 50 & 37 & 21 & 26 & 15 & 13 & 11 & 21 & 17 & 211 \\
GC7 & 26 & 38 & 25 & 29 & 16 & 18 & 19 & 18 & 22 & 211 \\
Total & 211 & 211 & 211 & 211 & 211 & 211 & 211 & 211 & 211 & \\
\hline
\end{tabular}

These results, applying Equation (1), present a ranking of the preferences and their normalized weights: GC6(0.157), SC1(0.130), SC2(0.125), GC7(0.125), GC3(0.116), GC4(0.111), GC5(0.101), GC2(0.068) and GC1(0.066). Therefore, the best valuated competences were capacity to apply knowledge practically (GC6), comprehension of financial operations in the business environment (SC1) and problem solving regarding financial valuation (SC2) and problem solving (GC7). The worst valuated competences were: capacity for analysis and synthesis (GC1), information management skills (GC2) and ability to work autonomously (GC5).

However, some studies obtained divergent results regarding the perception of the acquisition of some of these competences. For example, Ref. [58] collected the perceptions of 2556 students in ten Spanish public universities about their level of competence in ten competences, and found that, for students in this same branch of knowledge, the competence Autonomous Learning was among the three lowest rated competences, that is, with a poorer level of acquisition. However, in this study, the students scored it as one of the three least important competences. This suggests the need to incorporate lecturers' knowledge to ensure that gaps do not occur in the acquisition of certain skills.

To identify which teaching strategies fit better with the preferred competences as stated by the students, we asked the lecturers about the contribution of the strategies for the acquisition of the competences considered. The results of the assessments in relation to the teaching strategies are shown in Supplementary material (Tables S1-S5).

Finally, Table 5 summarizes the results of the votes of the 11 lecturers regarding teaching strategies (columns 2-6) and the valuations of the students for each competence (column 1) and shows the final score. Columns 2-6 present the normalized weights that represent the contribution of each teaching resource to the acquisition of each competence. The first column shows normalized weights in relation to the preferences of the students to each competence. The last row shows the final result obtained after applying Equation (5).

Table 5. Result of the votes for the teaching strategies. The figures in brackets show the normalized weight of each teaching strategy.

\begin{tabular}{cccccc}
\hline Students & \multicolumn{5}{c}{ Lecturers (Teaching Strategies) } \\
\hline Competences & $\mathbf{R} 1$ & $\mathbf{R} 2$ & $\mathbf{R 3}$ & $\mathbf{R} 4$ & $\mathbf{R 5}$ \\
\hline $\begin{array}{c}\text { SC1 } \\
{\left[\begin{array}{c}(0.102) \\
\text { SC2 }\end{array}\right.}\end{array}$ & $1(0.264)$ & $3(0.146)$ & $9(0.041)$ & $7(0.045)$ & $4(0.101)$ \\
\hline $8(0.087)]$ & $2(0.138)$ & $1(0.276)$ & $8(0.067)$ & $9(0.041)$ & $8(0.086)$ \\
\hline $\begin{array}{c}\mathrm{GC} 1 \\
{[5(0.092)]}\end{array}$ & $5(0.100)$ & $6(0.064)$ & $7(0.082)$ & $1(0.243)$ & $5(0.091)$ \\
\hline $\begin{array}{c}\mathrm{GC} 2 \\
{[7(0.087)]}\end{array}$ & $7(0.073)$ & $7(0.060)$ & $2(0.157)$ & $2(0.211)$ & $7(0.088)$ \\
\hline
\end{tabular}


Table 5. Cont.

\begin{tabular}{cccccc}
\hline Students & \multicolumn{5}{c}{ Lecturers (Teaching Strategies) } \\
\hline Competences & $\mathbf{R 1}$ & $\mathbf{R 2}$ & $\mathbf{R 3}$ & $\mathbf{R 4}$ & $\mathbf{R 5}$ \\
\hline $\begin{array}{c}\text { GC3 } \\
{[9(0.040)]}\end{array}$ & $6(0.083)$ & $8(0.058)$ & $3(0.143)$ & $3(0.133)$ & $9(0.055)$ \\
\hline $\begin{array}{c}\text { GC4 } \\
{[3(0.110)]}\end{array}$ & $3(0.123)$ & $5(0.067)$ & $6(0.100)$ & $6(0.086)$ & $3(0.109)$ \\
\hline $\begin{array}{c}\text { GC5 } \\
{[2(0.171)]}\end{array}$ & $4(0.111)$ & $9(0.048)$ & $5(0.115)$ & $4(0.108)$ & $2(0.167)$ \\
\hline $\begin{array}{c}\text { GC6 } \\
{[1(0.222)]}\end{array}$ & $8(0.062)$ & $2(0.171)$ & $1(0.169)$ & $5(0.091)$ & $1(0.216)$ \\
\hline $\begin{array}{c}\text { GC7 } \\
{[6(0.089)]}\end{array}$ & $9(0.046)$ & $4(0.109)$ & $4(0.125)$ & $8(0.042)$ & $7(0.088)$ \\
\hline Final score & 0.108174 & 0.115573 & 0.116242 & 0.106058 & 0.132343 \\
\hline
\end{tabular}

Applying Equation (5) we obtained the conjoined results, which consider the assessments of the students and lecturers. As a result of the aggregation of the student preferences in relation to the competences and the assessment of the lecturers in relation to the contribution of each resource of these competences, we obtained the final weights for each teaching resource: R5 (0.132343), R3 (0.116242), R2 (0.115573), R1 (0.108174) and R4 (0.106058). With the normalized weights, the final results about the distribution of the teaching strategies to cover the competences of the subject Financial Management were: activities related to the subject (0.229), group activities (0.201), practical lessons (0.2), theoretical lessons (0.187), and group presentations (0.183), respectively.

On the one hand, the results show a strong preference from the students for the competences linked to the most applied approach of the subject analyzed. As a result, the highest valuations refer to the competences: capacity to apply practical knowledge, comprehension of financial operations in the business environment and problem solving regarding financial valuation.

When the assessment of the teaching strategies of the lecturers were aggregated with the preferences of the students about the competences considered, the results recommended an increase in the efforts to develop activities, group work and practical classes. This is aligned with the quantitative approach of this subject and is probably aligned with the needs of the students regarding the intensity of the empirical work and the analytical explanations by the lecturers. These strategies are strongly related to applied classroom work. However, the teaching strategies that are linked to theoretical content seem less important for the students to achieve the competences of the subject Financial Management.

An important role of practical work is to help students develop links between observations and ideas. However, these ideas must be introduced [59]. Similar results regarding the perceived usefulness by students of quantitative subject matter strategies associated with exercise resolution have been found in other studies. Ref. [60] collected the perceptions of 55 first-year students of a semi-quantitative subject about the contribution of nine teaching strategies and found that students gave a higher score (84\%) to the degree of usefulness of the strategies associated with numerical exercise resolution and problems for the achievement of the general competences compared to other strategies. This greater practical emphasis was also found by [61] for the development of generic skills by undergraduates.

Although the case study only considers the competences defined in the teaching plan of the subject Financial Management and the teaching strategies used by the lecturers of this subject, the model is flexible enough to add, remove or change other competences related to other subjects or related to the same subject but not considered until now. 
Through the decision process it is possible to identify the most appropriate tools for the achievement of the most relevant skills and a flexible and participative assessment method that connects the preferences of the lecturers and the students. This permits the alignment of the teaching-learning goals and the teaching methods with the preferences of the students and the most relevant competences.

Likewise, this methodology is applicable when analyzing the suitability of new teaching strategies to apply in the teaching-learning process, to assess their utility and usability and quantify their contribution to the achievement of the competences related to a subject.

It would be interesting to complete this study with individual and group feedback from the students in order to validate their agreement with regard to the conjoint results. When identifying conflicts, it is recommendable to quantify them and develop some type of negotiation process to minimize the conflicts between lecturers and students to achieve a consensus.

The main limitation found in the case study is related to the continuity of the study with the same participants to define control mechanisms in order to validate the agreement between the individual assessment of the students and the conjoint results. This could be a problem if it were necessary to develop future negotiation processes.

However, this is the first study that proposes the participation of students in relation to the relevance of competences and the assessment of lecturers in a structured model and we tested the utility of the multi-criteria analysis for this proposal. Furthermore, it would be interesting to continue in this direction in order to improve the applicability of other mixed multi-criteria methods, to increase the operativity of the assessment system and to design mechanisms to pinpoint conflicts and develop negotiation processes between lecturers and students to ensure consensus.

\section{Conclusions}

The proposed model provides a formal methodology to aggregate the preferences of a group of students and lecturers about the competences related to a subject and the available teaching strategies. As a result, the methodology allows the analyst to obtain a combined student-lecturer opinion related to the use of each teaching resource for any one subject in order to achieve the necessary competences. Thereby, lecturers obtain useful information in order to lead the teaching-learning process that agrees with the expectations of the students and improves their motivation about any given subject.

In addition, this model not only allows us to obtain a ranking of the strategies that fit best with the expectations of the students, but it can also be useful to assess new "candidate-competences" or to analyze the elimination of others. Furthermore, it provides a methodology to design participative teaching plans based on competence-based learning, which treats the students as key stakeholders and participants in the teaching-learning process.

The case study allowed us to identify the most preferred competences of a group of students in relation to the subject Financial Management. The three competences most valued by the students were: capacity to apply knowledge practically, comprehension of financial operations in the business environment and problem solving regarding financial valuation. Additionally, it identified the best fitting teaching strategies: activities related to the subject, group activities and practical lessons.

The proposed methodology provides information about the best fitting teaching strategies for the teaching-learning process of any subject by aggregating the assessment of students and lecturers and permitting the identification of conflicts between them. This information could be used by management in higher education institutions to improve the quality of teaching plans. In addition, the model can be applied to different subjects and levels providing a formal method to obtain comparable information between institutions and improve quality in higher education organizations. 


\section{Limitations and Recommendations}

The main limitations found in the realization of this study were associated with data collection. Conducting student surveys is not without its difficulties. On the one hand, one must find the moment when students are most receptive to answering the survey. On the other hand, monitoring is extremely difficult, since groups of students change from one course to another. From a methodological perspective, the number of competencies and teaching strategies to be evaluated should not be excessively large. Although the proposed model is more flexible than the traditional AHP, if the number of criteria to be analyzed is very large, the evaluations can be excessively complex for non-expert participants.

Based on the results obtained that support previous studies, such as [62,63], a greater effective incorporation of students in the design of teaching learning process planning seems recommendable. However, to ensure the quality of the process it would also be advisable to integrate the knowledge of experts, in this case, lecturers and other key stakeholders. These processes should be designed following the ethical principles agreed in 2015 by the Academy of Social Sciences [64] to ensure that the integration of social agents is carried out in an integral, fair and responsible way, respecting the privacy, autonomy, diversity and values of individuals and communities.

Finally, reviewing and updating both the competences and the teaching strategies on a continuous basis is recommended, with the aim of aligning the teaching plans with innovations in the field of Higher Education. In addition, it is necessary to review the degree of agreement of the students with the teaching plans on a regular basis in order to detect possible negative effects such as the lack of motivation of some students.

This updating work should be transferred to the regulatory field. During the development of this work, it was found that the competences identified in the official documents of the teaching plans for the subjects should be reviewed according to the objectives of the subject and aimed at training students, not only from an academic perspective, but also from a labor perspective [25]. The university must be prepared to provide a quality, multidisciplinary education that forms professionals based on excellence, with broad knowledge, but also as citizens of future society.

Supplementary Materials: The following are available online at https:/ /www.mdpi.com/2227-739 0/9/1/9/s1, Table S1: Result of the voting process for the lecturers in relation to the contribution of the resource Theoretical lessons (R1), Table S2: Result of the voting process for the lecturers in relation to the contribution of the resource Practical lessons (R2), Table S3: Result of the voting process for the lecturers in relation to the contribution of the resource Group activities (R3), Table S4: Result of the voting process for the lecturers in relation to the contribution of the resource Group presentations (R4), Table S5: Result of the voting process for the lecturers in relation to the contribution of the resource Activities related to the subject (R5). Questionnaire Q1: Questionnaire addressed to students, Questionnaire Q2: Questionnaire addressed to lecturers.

Author Contributions: Conceptualization, P.L.-S., J.P., C.d.l.F.-C., and M.d.C.-P.; methodology, J.P. and M.d.C.-P.; software, J.P.; validation, J.P., C.d.l.F.-C., M.d.C.-P., formal analysis, P.L.-S., J.P., C.d.l.F.C., and M.d.C.-P.; investigation, C.d.l.F.-C. and M.d.C.-P.; resources, P.L.-S., C.d.l.F.-C. and M.d.C.-P. data treatment, J.P. and M.d.C.-P. writing - original draft preparation, P.L.-S., J.P., C.d.I.F.-C. and M.d.C.-P.; writing — review and editing, C.d.l.F.-C. and M.d.C.-P.; supervision, M.d.C.-P.; project administration, P.L.-S.; funding acquisition, P.L.-S. All authors have read and agreed to the published version of the manuscript.

Funding: This research received no external funding. The APC was funded by University Rey Juan Carlos-Seminario Permanente de Universitarios Emprendedores y Liderazgo.

Acknowledgments: The authors would like to acknowledge the valuable comments and recommendations made by four reviewers.

Conflicts of Interest: The authors declare no conflict of interest. 


\section{References}

1. Z Živković, Ž.; Nikolić, D.; Savić, M.; Djordjević, P.; Mihajlović, I. Prioritizing Strategic Goals in Higher Education Organizations by Using a SWOT-PROMETHEE/GAIA-GDSS Model. Group Decis. Negot. 2017, 26, 829-846. [CrossRef]

2. Van Vught, F.; Huisman, J. Institutional profiles: Some strategic tools. Tuning J. High. Educ. 2014, 1, 21-36. [CrossRef]

3. Waeraas, A.; Solbakk, M.N. Defining the essence of a university: Lessons from higher education branding. High. Educ. 2009, 57, 449. [CrossRef]

4. CESAER. Next Generation Metrics. White Paper Dated 10 June 2020. Available online: https://www.cesaer.org/content/5operations / 2020/20200610-white-next-generation-metrics.pdf (accessed on 9 December 2020).

5. Real Decreto 1393/2007, de 29 de Octubre, por el que se Establece la Ordenación de las Enseñanzas Universitarias Oficiales; AEBOE: Madrid, Spain.

6. Todose, D. Education management in knowledge based society. Contemp. Econ. 2008, 2, 109-117.

7. Dollinger, M.; Lodge, J.; Coates, H. Co-creation in higher education: Towards a conceptual model. J. Mark. High. Educ. 2018, 28, 210-231. [CrossRef]

8. Leal-Rodriguez, A.L.; Albort-Morant, G. Promoting innovative experiential learning practices to improve academic performance: Empirical evidence from a Spanish Business School. J. Innov. Knowl. 2019, 4, 97-103. [CrossRef]

9. ANECA, 2015. Standards and Guidelines for Quality Assurance in the European Higher Education Area (ESG). Available online: https:/ / enqa.eu/indirme/esg/ESG\%20in\%20Spanish_by\%20ANECA.pdf (accessed on 8 December 2020).

10. Martínez-Caro, E.; Cegarra-Navarro, J.C.; Cepeda-Carrión, G. An application on the performance-evaluation model for e-learning quality in higher education. Total Qual. Manag. Bus. Excell. 2014, 26, 1-16. [CrossRef]

11. Stevenson, S.; MacKeogh, K.; Sander, P. Working with student expectations of tutor support in distance education: Testing an expectations-led quality assurance model. Open Learn. 2006, 21, 139-152. [CrossRef]

12. Sander, P.; Stevenson, K.; King, M.; Coates, D. University students' expectations of teaching. Stud. High. Educ. 2000, 25, 309-323. [CrossRef]

13. Felder, R.M.; Brent, R. Understanding student differences. J. Eng. Educ. 2005, 94, 57-72. [CrossRef]

14. Lea, S.J.; Stephenson, D.; Troy, J. Higher education students' attitudes to student-centred learning: Beyond èducational bulimiá? Stud. High. Educ. 2003, 28, 321-334. [CrossRef]

15. Koenen, A.K.; Dochy, F.; Berghmans, I. A phenomenographic analysis of the implementation of competence-based education in higher education. Teach. Lect. Educ. 2015, 50, 1-12. [CrossRef]

16. Montalvo, S.; Palomo, J. Bridging the gap between teaching and breaking news: A new approach based on ESHE and ICT. Procedia Soc. Behav. Sci. 2010, 9, 1423-1428. [CrossRef]

17. De la Orden, C.; Palomo, J.; Figueroa-Domecq, C. Improving learning by motivating students to read the news using ICT. Glob. J. Bus. Econ. Manag. 2017, 7, 89-98.

18. Nafría, J.M.D.; Cendón, J.A.; Alonso, L.P. Building up eParticipatory decision-making from the local to the global scale. Study case at the European Higher Education Area. Comput. Hum. Behav. 2015, 47, 26-41. [CrossRef]

19. Visser-Wijnveen, G.J.; van der Rijst, R.M.; van Driel, J.H. A questionnaire to capture students' perceptions of research integration in their courses. High. Educ. 2016, 71, 473-488. [CrossRef]

20. Bergsmann, E.; Schultes, M.T.; Winter, P.; Schober, B.; Spiel, C. Evaluation of competence-based teaching in higher education: From theory to practice. Eval. Program Plan. 2015, 52, 1-9. [CrossRef]

21. EHEA Rome. 2020. Available online: http://ehea.info/Upload/Rome_Ministerial_Communique_Annex_III.pdf (accessed on 9 December 2020).

22. Turan, F.K.; Cetinkaya, S.; Ustun, C. A methodological framework to analyze stakeholder preferences and propose strategic pathways for a sustainable university. High. Educ. 2016, 72, 743-760. [CrossRef]

23. Henri, D.C.; Morrell, L.J.; Scott, G.W. Student perceptions of their autonomy at University. High. Educ. 2017, 75, 507-516. [CrossRef]

24. Segovia-Pérez, M.; Laguna-Sánchez, P.; de la Fuente-Cabrero, C. Education for Sustainable Leadership: Fostering Women's Empowerment at the University Level. Sustainability 2019, 11, 5555. [CrossRef]

25. Laguna-Sánchez, P.; Abad, P.; de la Fuente-Cabrero, C.; Calero, R. A University Training Programme for Acquiring Entrepreneurial and Transversal Employability Skills, a Students' Assessment. Sustainability 2020, 12, 796. [CrossRef]

26. González, J.; Wagenaar, R. Tuning Educational Structures in Europe. Final Report. Phase One; Universidad de Deusto: Bilbao, Spain, 2003.

27. Kampt, A. CESAER, 2019. Science \& Technology Education for 21st Century Europe. Available online: https://www.cesaer.org/ content/5-operations/2019/20191218-discussion-paper-st-education.pdf (accessed on 9 December 2020).

28. Hartog, J.; Vijverberg, W. Schools, skills and risk. Econ. Educ. Rev. 2007, 26, 758-770. [CrossRef]

29. Broadbent, J.; Poon, W.L. Self-regulated learning strategies and academic achievement in online higher education learning environments: A systematic review. Internet High. Educ. 2015, 27, 1-13. [CrossRef]

30. Sen, A. Development as Freedom; Oxford Paperbacks: Oxford, UK, 2001.

31. Ossadnik, W.; Schinke, S.; Kaspar, R.H. Group aggregation techniques for analytic hierarchy process and analytic network process: A comparative analysis. Group Decis. Negot. 2016, 25, 421-457. [CrossRef]

32. De Castro-Pardo, M.; Martínez, P.F.; Martínez, J.M.G.; Martín, J.M.M. Modelling Natural Capital: A Proposal for a Mixed Multi-criteria Approach to Assign Management Priorities to Ecosystem Services. Contemp. Econ. 2020, 14, 22-38. [CrossRef] 
33. Fernández Martínez, P.; de Castro-Pardo, M.; Martín Barroso, V.; Azevedo, J.C. Assessing Sustainable Rural Development Based on Ecosystem Services Vulnerability. Land 2020, 9, 222. [CrossRef]

34. Turan, F.K.; Needy, K.L. A quantitative decision model towards maximizing organizational sustainability. Eng. Manag. J. 2013, 25, 3-18. [CrossRef]

35. Vaidya, O.S.; Kumar, S. Analytic hierarchy process: An overview of applications. Eur. J. Oper. Res. 2006, 169, 1-29. [CrossRef]

36. Lee, S.M. Goal Programming for Decision Analysis; Auerbach Publishers: Philadelphia, PA, USA, 1972; pp. $252-260$.

37. Zadeh, L. Fuzzy sets. Inf. Control 1965, 8, 338-353. [CrossRef]

38. Kaya, I.; Çolak, M.; Terzi, F. A comprehensive review of fuzzy multi criteria decision making methodologies for energy policy making. Energy Strategy Rev. 2019, 24, 207-228. [CrossRef]

39. Saaty, T.L. Decision making-The analytic hierarchy and network processes (AHP/ANP). J. Syst. Sci. Syst. Eng. 2004, 13, 1-35. [CrossRef]

40. Zare, M.; Pahl, C.; Rahnama, H.; Nilashi, M.; Mardani, A.; Ibrahim, O.; Ahmadi, H. Multi-criteria decision making approach in E-learning: A systematic review and classification. Appl. Soft Comput. 2016, 45, 108-128. [CrossRef]

41. Shee, D.Y.; Wang, Y.S. Multi-criteria evaluation of the web-based e-learning system: A methodology based on learner satisfaction and its applications. Comput. Educ. 2008, 50, 894-905. [CrossRef]

42. Lin, T.C.; Ho, H.P.; Chang, C.T. Evaluation Model for Applying an E-Learning System in a Course: An Analytic Hierarchy Process-Multi-Choice Goal Programming Approach. J. Educ. Comput. Res. 2014, 50, 135-157. [CrossRef]

43. Chao, R.; Chen, Y. Evaluation of the criteria and effectiveness of distance e-learning with consistent fuzzy preference relations. Expert Syst. Appl. 2009, 36, 10657-10662. [CrossRef]

44. Lin, H.F. An application of fuzzy AHP for evaluating course website quality. Comput. Educ. 2010, 54, 877-888. [CrossRef]

45. Kennedy, G.E.; Cutts, Q.I. The association between students' use of an electronic voting system and their learning outcomes. J. Comput. Assist. Learn. 2005, 21, 260-268. [CrossRef]

46. Greenwood, N.A.; Howard, J.R. First Contact: Teaching and Learning in Introductory Sociology; Rowman \& Littlefield Publishers: Lanham, MD, USA, 2011.

47. Noguchi, H.; Ogawa, M.; Ishii, H. The appropriate total ranking method using DEA for multiple categorized purposes. J. Comput. Appl. Math. 2002, 146, 155-166. [CrossRef]

48. Fuh-Hwa, F.; Hui, L.H. The voting analytic hierarchy process method for selecting supplier. Int. J. Prod. Econ. 2005, 97, 308-317.

49. Wu, J.H.; Tennyson, R.D.; Hsia, T.L. A study of student satisfaction in a blended e-learning system environment. Comput. Educ. 2010, 55, 155-164. [CrossRef]

50. Marttunen, M.; Lienert, J.; Belton, V. Structuring problems for Multi-Criteria Decision Analysis in Practice: A Literature Review of Method Combinations. Eur. J. Oper. Res. 2017, 263, 1-17. [CrossRef]

51. De Castro-Pardo, M.; Urios, V. A critical review of multi-criteria decision making in protected areas. Econ. Agrar. Y Recur. Nat. Agric. Resour. Econ. 2017, 16, 89-109. [CrossRef]

52. Menezes, M.B.; da Silveira, G.J.; Drezner, Z. Democratic elections and centralized decisions: Condorcet and Approval Voting compared with Median and Coverage locations. Eur. J. Oper. Res. 2016, 253, 195-203. [CrossRef]

53. Saaty, T.L. How to make a decision: The analytic hierarchy process. Eur. J. Oper. Res. 1990, 48, 9-26. [CrossRef]

54. De Castro-Pardo, M.; de la Fuente-Cabrero, C.; Laguna-Sanchez, P.; Perez-Rodriguez, F. Combining AHP and Goal Programming in the context of the assessment of e-learning. Int. J. Anal. Hierarchy Process 2019, 11, 301-312. [CrossRef]

55. Nurmi, H. Voting procedures: A summary analysis. Br. J. Political Sci. 1983, 13, 181-208. [CrossRef]

56. Guaita Martínez, J.M.; Martín Martín, J.M.; Ostos Rey, M.S.; de Castro Pardo, M. Constructing Knowledge Economy Composite Indicators using an MCA-DEA approach. Econ. Res. Ekon. Istraživanja 2020, 1-21. [CrossRef]

57. El Gibari, S.; Gómez, T.; Ruiz, F. Building composite indicators using multicriteria methods: A review. J. Bus. Econ. 2019, 89, 1-24. [CrossRef]

58. Rodríguez Gómez, G.; Ibarra Saiz, M.S.; Cubero Ibáñez, J. Competencias básicas relacionadas con la evaluación. Un estudio sobre la percepción de los estudiantes universitarios. [Basic competences related to assessment: A study about university students' perception]. Educ. Xx1 2018, 2, 181-208.

59. Abrahams, I.; Millar, R. Does practical work really work? A study of the effectiveness of practical work as a teaching and learning method in school science. Int. J. Sci. Educ. 2008, 30, 1945-1969. [CrossRef]

60. Bautista, I. Generic competences acquisition through classroom activities in first-year agricultural engineering students. Int. J. Educ. Technol. High. Educ. 2016, 13, 1-9. [CrossRef]

61. Crebert, G.; Bates, M.; Bell, B.; Patrick, C.J.; Cragnolini, V. Developing Generic Skills at University, during Work Placement and in Employement: Graduates' Perceptions 2004. Available online: http:/ / citeseerx.ist.psu.edu/viewdoc/download?doi=10.1.1.460.4 757\&rep=rep1\&type $=$ pdf (accessed on 8 December 2020).

62. Ajjawi, R.; Tai, J.; Huu Nghia, T.L.; Boud, D.; Johnson, L.; Patrick, C.J. Aligning assessment with the needs of work-integrated learning: The challenges of authentic assessment in a complex context. Assess. Eval. High. Educ. 2020, 45, 304-316. [CrossRef]

63. Rudduck, J.; Fielding, M. Student voice and the perils of popularity. Educ. Rev. 2006, 58, 219-231. [CrossRef]

64. British Educational Research Association (BERA). Ethical Guidelines for Educational Research, 4th ed.; BERA: London, UK, 2018; Available online: https://www.bera.ac.uk/researchers-resources/publications/ethical-guidelines-for-educational-research-2018 (accessed on 9 December 2020). 